\section{Flood of discoveries in Nepal!}

\author{
Access to full text of world's 7000 leading journals \\ will revalue the role of TUCL
}

\section{Krishra M Bhandary}

S G ALBERT IS REPORTED TO HAVE SAID that research is to seewhateverybodyelsehas seen and to think what nobody else has thought. And, thinking to generatenew ideas should al ways be preceded by looking at the generated ideas. Since new knowledge is mostlyannounced viajournals, theyareindispensable components for scientists and experts both to get generated knowledge and to publish their new ones. Recently, there has been a remarkable progress in the former in Nepal.

In February2003the International Networkfor theAvailability of ScientificPublications (INASP), a cooperative network established in 1992 by the International Council for Science

y (ICSU)asaprogrammeoftheCommitteeforthe

Dissemination of Scientific Information (CDSI),

brary(TUCL) as National Coordinating Institute for the implementation of its Program for EnhancementofResearch Information (PERI). The purpose of this collaboration is availability of newknowledgein digital form to Nepal. September 2003, the full texts of 7,000 scholarlyjournals as well as abstracts and contents of 20,000 journals from around the world will be accessible at TUCL and certain other centresdesignated by TUCL. Thejournalsareprimarily technical, and represent a broad range of scientific fields, includingmedicine, agriculture, forestry, natural resource management, and engineering, as well as other fields in the social sciences, humanities and business administration.

As the increasing gap between haves and have-nots poses an increasing threat to world stability, it is essential that Nepal and other developing countries take steps to

List of selected PERI resources for Nepal

\begin{tabular}{ll}
\hline EBSCO & $\begin{array}{l}\text { Full text of 6000 journals; abstract and content of 7300 journalsin } \\
\text { all branches of science, technology, medicine, social science, } \\
\text { humanities }\end{array}$ \\
\hline Blackwell Synergy & $\begin{array}{l}\text { Full text of over 600 leading journals in natural, physical, and } \\
\text { social sciences; technology; medicine; and the humanities }\end{array}$ \\
\hline Springer Verlag & Full text of 432 high-quality journals in many disciplines \\
\hline Oxford University & $\begin{array}{l}\text { Full text of over 120 leading journals in science, technology, } \\
\text { medicine, humanities and social science }\end{array}$ \\
\hline Emerald & $\begin{array}{l}\text { Full text of 100 journals in marketing, business, engineering, } \\
\text { material science }\end{array}$ \\
\hline CAB Compendium & $\begin{array}{l}\text { Many journals in agriculture, forestry, management, and } \\
\text { conservation of natural resources }\end{array}$ \\
\hline Cochrane Library & Good resourcefor medical and health science \\
\hline
\end{tabular}
with Danish Ministry ofForeign Affairs (DMFA) ơ nominated Tribhuvan University Central Li- strengthen their scientific base. Researchers, academicians and students in Nepal are expected to benefitgreatly from theprogram. At present, they cannot purchase subscriptions to western journals even if they wish to. This availability of full-text database can radically alter theway they think and thewaythey conduct research, eventually leading to better designed research projects and to more productive application of established ideas. To a significant extent, this program is expected to fulfil the demand for research results in Nepal.

The information resources of PERI would normally cost over onemillion pounds sterling. PERI pays this sum to the publishers. These resources have been made availableto usfor $£ 27,500$. INASP has madearrangements to cover costsfor 2003. Bravo, DMFA!Although there is some hope of obtaining funding for 2004 and 2005 from DMFA and the International Department for Foreign Affairs (DFID), it would bewisest to think consider how costs can bemet if donors do not materialize. Once theinformation resourceis available, TUCL can offer access to other institutions at no further cost. TUCL is working out detailsfor extension of access to all libraries, research institutions, colleges and not-for-profit educational institutes throughout Nepal.

Promoting quality publications in the countries where the programmme is implemented is also one of the objectives of PERI which puts them on its websitefor worldwide dissemination. This would benefit Nepalese publication to get international recognition.

Krishna M Bhandaryislibrarian of Tribhuvan University Central Library, Kathmandu, Nepal. E-mail:tud@healthnet.org.np

\section{Marketing science journals

\author{
The wide circulation of a \\ journal is as important as
} its publication}

\section{Bharat B Shestha}

A HUGE AMOUNT OF INFORMATION IS generated every year in thefield of scienceand technology. Many scientists from different countriesareworkingon similartopicseither in co-operation or independently. The research findings of onescientistareimportant for othersin solvingmany problems. Research communication also avoids overlap in research and savestimeand resources. Theexchangeof information and ideas among them is very important to achievegoals earlier. Regular meeting between them is, however, impossible. Publication in electronic media or in printed form (e.g., journals) and widecirculation isthe most appropriate means of communication. Primary information is mostly fragmentary. These fragments should be distributed to the interested peoples. Research results will not have any meaning unless they are published and circulated. A good journal is a forum in which peoplesfrom different regions can communicate, shareideas, discuss and solve problems.

Therearealargenumber of good journals in the international market but very few have found their place in libraries of our university and research centers. Thisterriblelack of accesstosuch journalshampersour research and education al though their availabilityisnot going to make a great contribution to our research and development. Thisisbecausethere is a huge gap between the studies addressed by such journals and those conducted by our scientists. Journals published in Nepal are thereforecritically important, for theycan bea platform for our scientists.

When we count the number of science journals published in Nepal, perhapswearenot poor.Thisisgood news. Butthebad newsisthat many of them arevery poor in quality, irregular in publication and have very limited distribution. Theyareprinted on low-gradepaper with a shortlifespan. Manyannual journals arepublished at an interval of several years. For many journalsasingleissuebecomesthefirstand last. The Ministry of Science and Technology published thefirstissueof ScientificWorld in 1999and a second issuehas not appeared yet!

Limited distribution of published journalsisamajor problem in scientific communication. A journal is published, piled up in the publisher's office and ultimately damaged by silverfish or sold to a paper collector as waste paper. A better approach can besaleat reduced priceor freedistribution to interested people. Theproceedings of the first (1988) and second
-

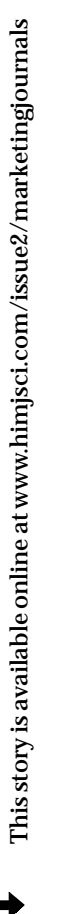

